\title{
Implementasi Hukuman Disiplin Jam Kerja Pegawai Negeri Sipil pada Badan Kepegawaian dan Pengembangan Sumber Daya Manusia Kota Tomohon
}

\author{
Aneke Nelwan \\ Program Studi Magister Ilmu Administrasi Negara
}

\begin{abstract}
Abstrak - Penelitian ini bertujuan untuk mendeskripsikan dan menganalisis Implementasi Hukuman Disiplin Jam Kerja Pegawai Negeri Sipil pada BKPSDM Kota Tomohon dilihat melalui empat (4) indikator dan faktor-faktor yang menghambat dalam proses Implementasinya. Penelitian ini menggunakan pendekatan kualitatif dengan Teknik pengumpulan data yaitu melalui wawancara, observasi dan dokumentasi. Penelitian ini menyimpulkan bahwa disiplin jam kerja di BKPSDM telah diterapkan meskipun masih terdapat misskomunikasi atau kurangnya koordinasi antara pimpinan dan bawahan, kurangnya komitmen dan tanggung jawab dalam menyelesaikan tugas yang diberikan pimpinan serta kurangnya kepedulian atau dukungan dari pimpinan baik dukungan moral dan dukungan moril dalam memberikan tugas-tugas kantor. Hal tersebut akan mempengaruhi prestasi kerja, namun dapat memelihara dan meningkatkan disiplin yang baik bukan hal yang mudah, karena banyak faktor yang mempengaruhinya. Peraturan
\end{abstract} Pemerintah (PP) Nomor 53 Tahun 2010 tentang Disiplin Pegawai Negeri Sipil merupakan pedoman perilaku bagi PNS [1]. Terdapat Faktor-faktor yang menghambat pada Implementasi Hukuman Disiplin Jam Kerja PNS pada BKPSDM, yaitu: komunikasi yang kurang efektif, sumber daya pegawai dan peralatan yang terbatas, belum tersedianya SOP tentang penjatuhan hukuman disiplin di setiap bidang, dan kurang tegasnya atasan dalam pengambilan keputusan serta belum dilakukannya pemberian reward dan punishment terhadap PNS yang tepat waktu dalam menyelesaikan pekerjaan kantor.

Kata Kunci : Implementasi, Hukuman Disiplin Jam Kerja Pegawai Negeri Sipil pada BKPSDM Kota Tomohon

\section{PENDAHULUAN}

Penjatuhan hukuman disiplin dimaksudkan untuk membina Pegawai Negeri Sipil yang telah melakukan pelanggaran, agar yang bersangkutan mempunyai sikap menyesal dan berusaha tidak mengulangi dan memperbaiki diri pada masa yang akan datang. Hal ini dimaksudkan juga sebagai pedoman bagi pejabat yang berwenang menghukum serta memberikan kepastian dalam menjatuhkan hukuman disiplin. Dalam Peraturan Pemerintah tersebut secara tegas disebutkan jenis hukuman disiplin yang dapat dijatuhkan terhadap suatu pelanggaran disiplin. Jenis-jenis hukuman disiplin tersebut berdasarkan Peraturan Pemerintah Nomor 53 Tahun 2010 yaitu hukuman ringan, hukuman sedang dan hukuman berat [1].

Dari sekian lama Peraturan Pemerintah tersebut dikumandangkan, seyogyanya PNS sudah mengetahui atau paling tidak pernah mendengar tentang Peraturan Pemerintah tersebut baik 
melalui membaca peraturan, mendapat materi Pelatihan Dasar bagi CPNS, bimbingan teknis kepegawaian, maupun melalui sosialisasi.

Selanjutnya di jabarkan dalam Pasal 1 ayat (3) bahwa Pelanggaran disiplin adalah setiap ucapan, tulisan, atau perbuatan PNS yang tidak menaati kewajiban dan/atau melanggar larangan ketentuan disiplin PNS, baik yang dilakukan di dalam maupun di luar jam kerja.

\section{Menurut hasil pengamatan} penulis, memang ada beberapa pelanggaran disiplin jam kerja yang dilakukan oleh PNS di lingkungan BKPSDM Kota Tomohon diantaranya masuk dan pulang kerja tidak tepat waktu, main game secara online, facebook pada saat jam kerja, nonton streaming secara online dengan menggunakan laptop/komputer kantor, serta ada beberapa PNS yang tidak tepat waktu dalam menyelesaikan pekerjaan kantor sesuai dengan batas waktu yang ditetapkan, bahkan ada beberapa PNS yang telah dijatuhi hukuman disiplin tetapi masih saja belum jera. Kondisi seperti ini mencerminkan kurang kondusif dalam masalah disiplin jam kerja pada BKPSDM Kota Tomohon. Penelitian ini bertujuan untuk mendeskripsikan dan menganalisis Implementasi Hukuman Disiplin Jam Kerja Pegawai Negeri Sipil pada BKPSDM Kota Tomohon dilihat melalui empat (4) indikator dan faktor-faktor yang menghambat dalam proses Implementasinya.

\section{KAJIAN TEORITIK}

\section{A. Kebijakan Publik}

Pendapat Edwards III dan Sharkansky yang menyatakan bahwa "Kebijakan Negara adalah suatu tindakan yang dilakukan atau tidak dilakukan pemerintah", sehingga suatu kebijakan tidak hanya suatu tindakan yang diusulkan tetapi juga yang tidak dilaksanakan [2]. Demikian pula pendapat Dye, yang mengatakan kebijakan publik adalah apapun pilihan pemerintah untuk melakukan atau tidak melakukan [2].

Menurut Dye mengemukakan; Public Policy is what governments chooce to do or not to do. Maksudnya kebijakan adalah apapun pilihan pemerintah untuk melakukan sesuatu atau tidak melakukan sesuatu. Itu berarti bahwa apabila pemerintah memilih untuk melakukan sesuatu, artinya pemerintah mempunyai tujuan tertentu yang membutuhkan tindakan (implementasi). Artinya bahwa kebijakan publik adalah tindakan pemerintah berdasarkan pilihan-pilihan yang ada. Demikian pula, apabila pemerintah mempunyai alasan tertentu dan itupun adalah suatu kepentingan publik [3].

$$
\text { Berdasarkan pengertian- }
$$

pengertian kebijakan publik diatas, maka disimpulkan bahwa kebijakan adalah serangkaian tindakan pemerintah yang bersifat mengatur dalam rangka merespon permasalahan yang dihadapi masyarakat dan mempunyai tujuan tertentu, berorientasi kepada kepentingan publik (masyarakat) dan bertujuan untuk mengatasi masalah, memenuhi keinginan dan tuntutan seluruh anggota masyarakat. Kebijakan juga memuat semua tindakan pemerintah baik yang dilakukan maupun tidak dilakukan yang dalam pelaksanaannya terdapat unsur pemaksaan kepada pelaksana atau pengguna kebijakan. Hal ini sejalan dengan pendapat Easton bahwa kebijakan mengandung nilai paksaan yang secara sah dapat dilakukan pemerintah sebagai pembuat kebijakan. 


\section{B. Konsep Implementasi Kebijakan}

Setelah sebuah kebijakan di formulasikan, langka selanjutnya tentu saja mengimplementasikan kebijakan tersebut. Mengenai implementasi kebijakan, menyatakan : "Rencana adalah $20 \%$ keberhasilan, implementasi adalah $60 \%$ sisanya, $20 \%$ sisanya adalah bagaimana kita mengandalkan implementasi" [4].

Tujuan dari kebijakan publik yang telah formulasikan dapat dicapai melalui pelaksanaan kebijakan tersebut atau diistilahkan dengan implementasi kebijakan atau dengan kata lain implementasi adalah tindakan yang dilakukan setelah suatu kebijakan ditetapkan.

Menurut Kamus Webster implementasi "to implementation" (mengimplementasikan) berarti "to provide means for carrying out"; "to give practical effect to" (menimbulkan dampak/berakibat sesuatu) [5].

Berdasarkan definisi diatas maka Implementasi kebijakan publik pada prinsipnya adalah cara agar sebuah kebijakan dapat mencapai tujuannya, tidak lebih dan tidak kurang untuk mengimplementasikan dalam bentuk program atau melalui formulasi kebijakan.

\section{Model-Model Kebijakan}

\section{Model Van Meter dan Van Hom}

Model pertama adalah model yang paling klasik, yakni model yang diperkenalkan oleh Meter dan Hom [4]. Model ini mengandaikan bahwa implementasi kebijakan berjalan secara linear dari kebijakan publik, implementator dan kinerja kebijakan publik. Ada 6 variabel yang dimasukkan sebagai variabel, yaitu:
1) Standard an sasaran kebijakan; 2) Sumberdaya; 3) Hubungan antar organisasi; 4) Karakteristik agen pelaksana; 5) Disposisi implementor; 6) Kondisi lingkungan social, politik dan ekonomi.

\section{Model Mazmanian dan Sabatier}

Model yang kedua adalah model yang dikembangkan Mazmanian dan Sabatier) yang mengemukakan bahwa implementasi adalah upaya melaksanakan keputusan kebijakan [4].

\section{Model Hogwood dan Gunn}

Model ketiga adalah Model Brian W. Hogwood dan Lewis A. Gunn) untuk dapat mengimplementasikan kebijakan secara sempurna, maka diperlukan beberapa persyaratan tertentu. Syarat-syarat itu adalah [4]:

a. Kondisi eksternal yang dihadapi oleh badan/instansi pelaksana tidak akan menimbulkan masalah yang besar. Hambatan-hambatan diantaranya mungkin bersifat fisik maupun politis.

b. Untuk pelaksanaan program apakah sudah tersedia sumberdaya yang cukup memadai, termasuk sumberdaya waktu. Syarat kedua ini sering muncul diantara kendalakendala yang bersifat eksternal.

c. Perpaduan sumber-sumber yang diperlukan benar-benar memadai. Persyaratan ini mengikuti syarat item kedua artinya disatu pihak harus dijamin tidak ada kendalakendala pada semua sumber-sumber yang diperlukan, dan dilain pihak, setiap tahapan proses implementasi perpaduan diantara sumber-sumber tersebut harus dapat disediakan.

d. Kebijakan yang akan diimplementasikan didasari oleh suatu hubungan kausalitas yang andal. Kebijakan kadangkala tidak 
dapat diimplementasikan secara efektif bukan telah diimplementasikan secara asalasalan, tetapi kebijakan itu sendiri memang jelek.

e. Hubungan kausalitas bersifat langsung dan hanya sedikit mata rantai penghubungnya. Dengan kata lain semakin banyak hubungan dalam mata rantai, semakin besar pula resiko bahwa beberapa diantaranya kelak terbukti amat lemah atau tidak dapat dilaksanakan dengan baik.

f. Hubungan saling ketergantungan kecil. Implementasi yang sempurna menuntut adanya persyaratan bahwa hanya terdapat badan pelaksana tunggal dalam melaksanakan misi tidak tergantung badan-badan lain/instansi lainnya.

g. Pemahaman yang mendalam dan kesepakatan terhadap tujuan.

Persyaratan ini mengharuskan adanya pemahaman yang menyeluruh mengenai kesepakatan terhadap tujuan yang akan dicapai dan dipertahankan selama proses implementasi.

\section{Model Grindle}

Model Implementasi Kebiajakn publik yang dikemukakan Grindle menurut menuturkan bahwa keberhasilan proses implementasi kebijakan sampai kepada tercapainya hasil tergantung kepada Content of Policy dan Conteks of Implementation

(konteks implementasinya), selain dipengaruhi oleh kegiatan program yang telah dirancang dan pembiayaan cukup [4].

\section{Model Elmore, dkk}

Model kelima menurut Nugroho adalah model yang disusun Richard Elmore, Michael Lipsky, dan Benny Hjem dan David O'Porter. Model ini dimulai dari mengidentifikasikan jaringan actor yang terlibat dalam proses pelayanan dan menanyakan kepada mereka: tujuan, strategi, aktivitas, dan kontak-kontak yang mereka miliki. Model Implementasi ini didasarkan pada jenis kebijakan public yang mendorong masyarakat untuk mengerjakan sendiri implementasi kebijakannya atau tetap melibatkan pejabat pemerintah [4].

\section{Model George C.Edwards}

Teori implementasi kebijakan yang berperspektif top-down dikembangkan oleh Edward III. Dalam pendekatan yang dikemukakan oleh Edward III, terdapat empat variabel yang sangat menentukan keberhasilan implementasi suatu kebijakan, yaitu: komunikasi; sumber daya; disposisi; dan struktur birokrasi.

\section{Pengertian Disiplin}

Disiplin Pegawai Negeri Sipil menurut Peraturan Pemerintah Nomor 53 Tahun 2010 adalah: Kesanggupan Pegawai Negeri Sipil untuk menaati Kewajiban dan menghindari larangan yang ditentukan dalam peraturan perundang-undangan dan/atau peraturan kedinasan yang apabila tidak ditaati atau dilanggar dijatuhi hukuman disiplin. Hukuman Disiplin adalah hukuman yang dijatuhkan kepada PNS karena melanggar peraturan disiplin PNS [1].

Menurut Lateiner dan Levine, disiplin memiliki dua aspek yaitu disiplin waktu dan disiplin kerja [6].

\section{E. Regulasi PP Nomor 53 Tahun 2010}

Dalam Peraturan Pemerintah Nomor 53 Tahun 2010 Bab 1 Pasal 1 ayat (3) bahwa Pelanggaran disiplin adalah setiap ucapan, tulisan, atau perbuatan PNS yang tidak menaati kewajiban 
dan/atau melanggar larangan ketentuan disiplin PNS, baik yang dilakukan di dalam maupun di luar jam kerja. Pasal 1 ayat (4) Hukuman disiplin adalah hukuman yang dijatuhkan kepada PNS karena melanggar peraturan disiplin PNS [1].

\section{METODE PENELITIAN}

Penelitian ini dilakukan melalui pendekatan kualitatif dengan cara ikut berperan serta dalam interaksi sosial, melakukan wawancara mendalam ataupun dengan menggunakan teknik pengumpulan data secara triangulasi/gabungan dan mengetahui Hukuman disiplin apa saja yang diterima PNS yang tidak disiplin dalam hal disiplin jam kerja pada Badan Kepegawaian dan Pengembangan Sumber Daya Manusia (BKPSDM), serta faktor-faktor yang mendukung kurangnya kesadaran pegawai dalam Implementasi Hukuman Disiplin Jam Kerja pada BKPSDM Kota Tomohon.

Beberapa kegunaan Metode Penelitian Kualitatif adalah untuk memahami proses atau interaksi sosial, memahami perasaan orang, dan untuk memastikan kebenaran data [7].

Fokus penelitian bersifat tentatif seiring dengan perkembangan penelitian. Moleong menyatakan bahwa fokus penelitian dimaksudkan untuk membatasi studi kualitatif, sekaligus membatasi penelitian guna memilih data yang relevan dan yang baik. Dalam penelitian ini, peneliti memfokuskan penelitian pada pemberian Hukuman Disiplin terhadap PNS yang tidak disiplin dalam hal disiplin jam kerja atau disiplin dalam penggunaan waktu secara efektif dilihat melalui empat (4) indicator [8].
Lokasi Penelitian adalah di Badan Kepegawaian dan Pengembangan Sumber Daya Manusia Kota Tomohon.

Dalam penelitian ini, data sekunder diperoleh dari: (1) Sekretariat Badan Kepegawaian dan Pengembangan Sumber Daya Manusia Kota Tomohon (Sekretaris BKPSDM, Kepala Sub bagian

Umum,Kepegawaian,Perencanaan dan Hukum, Staf); (2) Bidang Pengembangan Kompetensi dan Penilaian Kinerja Aparatur (Kepala Bidang, Kepala Sub Bidang Penilaian Kinerja Aparatur, Kepala Sub Bidang Penghargaan dan Disiplin Aparatur, Staf).

\section{HASIL PENELITIAN DAN PEMBAHASAN}

\section{Hukuman Disiplin Jam Kerja Pegawai Negeri Sipil pada BKPSDM Kota Tomohon}

Berdasarkan data dan hasil penelitian yang didapat, diketahui bahwa pada dasarnya pemberian hukuman disiplin PNS pada BKPSDM sudah sesuai dengan Peraturan Pemerintah Nomor 53 Tahun 2010. Dalam pemberian Hukuman Disiplin Jam Kerja Pegawai Negeri Sipil pada BKPSDM Kota Tomohon dilihat melalui empat (4) indikator, yaitu:

\section{Frekwensi kehadiran pegawai di kantor pada hari kerja, ketepatan jam masuk dan pulang kantor}

Disiplin Pegawai Negeri Sipil menurut Peraturan Pemerintah Nomor 53 Tahun 2010 adalah: Kesanggupan Pegawai Negeri Sipil untuk menaati Kewajiban dan menghindari larangan yang ditentukan dalam peraturan perundang-undangan dan/atau peraturan 
kedinasan yang apabila tidak ditaati atau dilanggar dijatuhi hukuman disiplin.

\section{Pelaksanaan disiplin berarti} kepatuhan individu atau kelompok pada norma, kaidah, hukum, aturan, prosedur dan system sebagai suatu keharusan. Individu dalam organisasi dalam melaksanakan tugasnya berusaha tepat waktu. Ketepatan waktu adalah bagian yang penting dalam tata tertib yang mencantumkan jam kerja PNS yang ada di BKPSDM Kota Tomohon. Mengenai disiplin terhadap jam kerja Menurut Lateiner dan Levine (Soeprapto, 2000:49), misalnya melalui sistem daftar absensi yang baik atau sistem apel, dapat dipantau secara tepat dan cepat.

Berdasarkan data dan hasil penelitian menunjukkan bahwa dalam hal pemberian hukuman disiplin bagi PNS pada BKPSDM yang tidak disiplin sudah dilaksanakan berupa teguran lisan maupun teguran tertulis tetapi masih saja ada pegawai yang mengulangi pelanggaran tersebut.

2. Prestasi kerja/kinerja sesuai dengan Sasaran Kerja Pegawai

Penilaian kinerja PNS adalah
proses pengukuran keberhasilan
pencapaian kinerja yang ditunjukan oleh
PNS yang akan dinilai oleh atasan dalam bentuk penilaian prestasi kerja, sedangkan capaian kinerja adalah hasil kerja yang dicapai oleh PNS di lingkungan BKPSDM Kota Tomohon yang diukur berdasarkan realisasi keberhasilan PNS sesuai dengan waktu yang ditetapkan. Sebagaimana dikemukakan oleh Carrell, Elbert, dan Hatfield mengemukakan bahwa disiplin merupakan bagian yang menjiwai keseluruhan fungsi-fungsi manajemen untuk meningkatkan kinerja setiap individu dalam organisasi. Berarti semua kegiatan tanpa disiplin tidak akan menghasilkan sesuatu kinerja yang bermanfaat. Ungkapan Carell, dkk tersebut sangat jelas, ia mengemukakan pekerjaan apapun termasuk membangun komunikasi jika tidak dilakukan tanpa disiplin tidak akan menghasilkan sesuatu kinerja yang bermanfaat [9].

Realita yang terjadi pada PNS yang ada di BKPSDM terdapat masih ada pegawai yang belum optimal dalam melaksanakan tugasnya, karena pegawai tersebut kurang mengerti dengan tugas pokok dan fungsinya sebagai pegawai BKPSDM. sehingga sasaran kerja pegawai tidak dicapai sesuai dengan target yang diharapkan oleh atasan langsung. Untuk pemberian hukuman kepada PNS yang tidak disiplin dalam hal tidak tepat waktu dalam pekerjaan yang diberikan atau tidak mencapai Sasaran Kerjanya, diberikan teguran secara lisan dan pemotongan TPP sebesar 3\% sesuai dengan pengurangan yang ada dalam aplikasi TPP. Ini berarti bahwa kinerja PNS BKPSDM terlihat dari perilaku mereka dalam melaksanakan tugas apakah sesuai dengan rencana kerja, melaksanakan tugas sesuai aturan, menguasai pekerjaan yang menjadi tanggung jawabnya, dan apakah PNS loyal dalam melaksanakan pekerjaannya. Hal-hal tersebut adalah salah satu bagian dari perilaku kerja PNS.

Dengan kinerja yang baik maka akan mendapatkan penilaian yang baik yang akhirnya akan menempatkan sesorang pada jabatan yang lebih baik.

\section{Ketaatan pegawai dalam mengikuti pedoman kerja yang ditentukan}

Sebagian besar PNS yang ada di BKPSDM telah mengetahui tentang 
regulasi/aturan tentang Peraturan Pemerintah Nomor 53 Tahun 2010 yang memuat pedoman tentang Disiplin Pegawai Negeri Sipil, tetapi masih saja ada beberapa PNS yang tidak taat/patuh terhadap aturan tersebut, akan tetapi sebagian PNS di BKPSDM ada pula yang taat dalam mengikuti pedoman kerja, baik itu sesuai tupoksi maupun aturanaturan pemerintah yang lainnya.

Bagi PNS yang kurang bertanggung jawab atas pekerjaannya, pimpinan atau atasan langsung harus bertanggung jawab, karena secara struktur yang menggerakkan pegawai untuk melaksanakan tugas kerjanya adalah pimpinan.Bila pimpinan mampu menggerakkan para pegawainya dalam melaksanakan tugasnya, maka pegawai akan taat terhadap aturan yang berlaku. Seperti yang dikemukakan oleh kepemimpinan ditunjukkan oleh kemampuan yang dimiliki oleh seseorang yang bertindak sebagai pemimpin untuk mempengaruhi kelompok untuk mencapai visi dan misi serta tujuan yang ditetapkan [10]. Seorang pemimpin dalam melaksanakan tugasnya harus mampu memberikan dorongan kepada para bawahannya dalam melaksanakan pekerjaan, sehingga pekerjaan dapat diselesaikan dalam suasana kondusif tanpa tekanan atau keterpaksaan, tetapi selalu mengacu pada aturan dan ketentuan yang berlaku dalam organisasi.

\section{Motivasi pegawai dalam menyelesaikan pekerjaannya yang diberikan}

Dame, J.M, hasil penelitiannya menjelaskan bahwa bagi pegawai, tingkat disiplin kerja yang tinggi dapat memberikan keuntungan tersendiri, memperluas kesempatan untuk dipromosikan, serta membuat ia semakin ahli dan berpengalaman dalam bidang pekerjaannya [11]. Sebaliknya, tingkat disiplin kerja pegawai yang rendah menunjukkan bahwa pegawai tersebut sebenarnya tidak kompeten dalam pekerjaannya, akibatnya ia sukar untuk dipromosikan ke jenjang pekerjaan yang tingkatannya lebih tinggi, memperbesar kemungkinan untuk didemosikan, dan pada akhirnya dapat juga menyebabkan pegawai tersebut mengalami pemutusan hubungan kerja.

Berdasarkan data dan hasil penelitian menunjukkan bahwa perlu adanya dukungan dari pimpinan, baik berupa dukungan secara moral maupun dukungan secara moril baik berupa pendampingan dari atasan maupun dalam arti atasan kurang memberikan semangat ataupun membantu dalam penyelesaian pekerjaan tersebut. Hal ini yang mengakibatkan PNS tidak termotivasi dalam menyelesaikan pekerjaan yang diberikan oleh atasan langsung.

\section{Faktor-faktor yang menghambat dalam Implementasi Hukuman Disiplin Jam Kerja Pegawai Negeri Sipil pada BKPSDM Kota Tomohon}

Dalam menjalankan sebuah kebijakan, tahap implementasi adalah tahapan yang penting untuk menentukan apakah kebijakan yang telah disusun oleh pemerintah sudah berhasil sesuai dengan perencanaan. Output dari kebijakan dalam penelitian ini adalah dihasilkannya implementasi pemberian hukuman disiplin jam kerja PNS pada BKPSDM Kota Tomohon. Untuk itu perlu diketahui faktor apa saja yang bisa menghambat proses implementasi hukuman disiplin, agar output yang diharapkan bisa berhasil. 
Sehubungan dengan hasil penelitian diatas dan yang menjadi objek temuan peneliti adalah: Implementasi Hukuman Disiplin Jam Kerja PNS pada Badan Kepegawaian dan Pengembangan Sumber Daya Manusia Kota Tomohon, dan peneliti mendapatkan pusat perhatian dalam penelitian kualitatif ini, yaitu dimana peneliti berusaha mencari fakta dan data terlebih dahulu, baru kemudian selanjutnya menggunakan landasan teori Implementasi Kebijakan publik yang dikemukakan oleh Edward III dan konsep secara normativ yakni Peraturan Pemerintah Nomor 53 Tahun 2010 tentang Disiplin Pegawai Negeri Sipil.

Adapun faktor-faktor yang mempengaruhi keberhasilan proses implementasi suatu kebijakan menurut Edward III, adalah sebagai berikut :

\section{Komunikasi}

Dari hasil penelitian, ditemukan bahwa terdapat miss komunikasi dalam hal pemberian keterangan ijin pegawai, karena untuk mempercepat proses pencairan TPP kadang belum dikonfirmasi terlebih dahulu kepada atasan langsung secara berjenjang apakah alasan dari PNS tersebut benar adanya, apakah disetujui atau tidak disetujui oleh atasannya terlebih dahulu, jika atasannya keberatan, maka surat keterangan tersebut diubah sesuai dengan pernyataan atasannya dan hal ini menyebabkan keterlambatan dalam pengumpulan data.Juga terdapat komunikasi yang kurang efektif seperti terdapat kebijakankebijakan yang berbeda antara bidang yang satu dengan bidang yang laiinya dalam hal pengurangan/pemotongan TPP maupun terhadap pemberian hukuman disiplin, sehingga menimbulkan kecemburuan diantara PNS BKPSDM.
Kejelasan informasi atas data yang diminta merupakan hal sangat penting. Penyaluran komunikasi yang baik akan dapat menghasilkan suatu implementasi yang baik pula. Seringkali yang terjadi dalam penyaluran komunikasi adalah adanya salah pengertian (miskomunikasi). Kejelasan informasi atas data yang diminta merupakan hal sangat penting, karena ini dapat menjadi hambatan dalam pengumpulan data.

\section{Sumber Daya}

Selanjutnya hambatan yang muncul berkaitan dengan masalah sumber daya yaitu sumber daya manusia dan peralatan. Sumber daya disini dapat diartikan sebagai kemampuan atau keahlian dari para pelaksana kebijakan, kewenangan yang dimiliki, serta fasilitas-fasilitas yang dapat dipakai untuk melaksanakan hukuman disiplin PNS. Sumber daya yang dimiliki oleh BKPSDM Kota Tomohon sebagai pelaksana kebijakan adalah harus yang memadai dalam arti harus paham akan regulasi tentang Disiplin Pegawai Negeri Sipil, sehingga akan membantu pelaksanaan dalam pengambilan keputusan dan juga ketersediaan informasi dan fasilitas yang memadai.

\section{Disposisi / Sikap}

Dalam penelitian ini terdapat permasalahan yang lain yaitu sehubungan dengan pemberian hukuman disiplin pada BKPSDM Kota Tomohon, bahwa atasan tidak mengetahui keadaan/situasi yang sebenarnya terjadi dikantor karena atasan sering melakukan perjalanan dinas luar daerah sehingga tindaklanjut terhadap PNS yang telah terkena hukuman disiplin menjadi terhambat. Hal tersebut membuktikan 
bahwa atasan memberikan perintah tanpa melakukan monitoring terhadap apa yang diperintahkan dan tidak adanya penilaian atasan pada tugas-tugas kantor yang diberikan. Mazmanian dan Sabatier (Nugroho 2003:169) mengemukakan bahwa variabel intervening yang di dalamnya termasuk dukungan pejabat yang lebih tinggi serta komitmen dan kualitas kepemimpinan dari pejabat pelaksana sebagai hal yang menentukan berhasilnya suatu implementasi kebijakan. Jika pimpinan selalu melakukan monitoring atas kinerja bawahannya, maka dipastikan hasil kerja bawahan akan sesuai dengan keinginan atasan. Berhasil atau tidaknya suatu pekerjaan yang dikerjakan oleh bawahan, maka atasan wajib memberikan penilaian atas hasil kerja bawahan, terlepas dari baik atau buruknya pekerjaan bawahan tersebut. Dengan melakukan penilaian atas kinerja bawahan maka akan menimbulkan kepedulian bawahan atas pekerjaannya karena merasa di perhatikan.

\section{Struktur Birokrasi}

Dari hasil penelitian bahwa di BKPSDM sudah ada SOP tentang penjatuhan hukuman disiplin PNS dan informan juga mengetahui betapa pentingnya SOP penjatuhan hukuman disiplin PNS, akan tetapi SOP tersebut tidak di publikasikan secara luas, sehingga tidak semua PNS yang ada di BKPSDM mengetahui akan SOP hukuman disiplin PNS tersebut.

Perlu dipahami bahwa SOP diperlukan sebagai pedoman dalam mengerjakan suatu tugas, dengan adanya SOP dapat diketahui proses langkahlangkah yang harus dilakukan, buktibukti apa yang harus disiapkan serta berapa waktu yang diperlukan dalam menyelesaikan proses penjatuhan hukuman disiplin PNS tersebut.

Melihat kondisi seperti ini tidak menutup kemungkinan ada kendalakendala yang dihadapi dalam mengimplementasikan hukuman disiplin jam kerja PNS pada BKPSDM Kota Tomohon dikarenakan atasan langsung atau pejabat yang berwenang belum sepenuhnya memahami prosedur yang ada dalam arti penerapan dan cara melakukan pemeriksaan apabila terjadi pelanggaran yang dilakukan oleh PNS tersebut.

Penerapan disiplin jam kerja PNS pada BKPSDM Kota Tomohon baru dipahami sebatas tingkat kehadiran pegawai yang dibuktikan dengan daftar hadir (finger print), sedangkan penerapan disiplin ketepatan waktu dalam menyelesaikan pekerjaan yang diberikan oleh atasan langsung hanya dilakukan teguran secara lisan.

Disiplin pegawai dalam bekerja akan berdampak pada peningkatan karier dan pengembangan potensi-potensi yang dimilikinya untuk siap mengikuti uji kompetensi dalam era keterbukaan dan transparansi untuk menduduki posisi jabatan yang dikenal dengan istilah lelang jabatan, walaupun untuk kedepannya akan ada perampingan eselon atau penyederhanaan birokrasi baik di pemerintahan pusat maupun pemerintahan yang ada di daerah.

Dari uraian diatas terlihat bahwa Implementasi Hukuman Disiplin Jam Kerja PNS pada Badan Kepegawaian dan Pengembangan Sumber Daya Manusia Kota Tomohon sudah dilaksanakan namun belum sepenuhnya diterapkan. Terkait faktor-faktor yang menghambat pada Implementasi Hukuman Disiplin 
Jam Kerja PNS pada BKPSDM, yaitu: ditemuinya hambatan-hambatan sebagai berikut: koordinasi, komunikasi yang kurang efektif, sumber daya pegawai dan peralatan yang terbatas, belum tersedianya SOP tentang penjatuhan hukuman disiplin di tiap bagian, sikap mental PNS belum menunjukkan keseriusan bahwa pentingnya disiplin jam kerja, baik dalam kehadiran maupun tepat waktu dalam penyelesaian tugastugas kantor dan kurang tegasnya atasan dalam pengambilan keputusan serta belum adanya dukungan dari pihak-pihak yang memiliki wewenang kekuasaan dengan memberikan reward dan punishment. Jika proses pelaksanaan Implementasi kebijakan ini sudah dilaksanakan dengan memperhatikan hal-hal tersebut, maka pelaksanaan implementasi kebijakan ini akan berjalan dengan baik tanpa ada hambatan yang berarti.

\section{SIMPULAN}

1. Disiplin Jam Kerja merupakan salah satu fungsi yang terpenting dan harus diterapkan bagi seluruh PNS, demikian disiplin jam kerja di BKPSDM telah diterapkan meskipun masih terdapat misskomunikasi atau kurangnya koordinasi antara pimpinan dan bawahan, kurangnya komitmen dan tanggung jawab dalam menyelesaikan tugas yang diberikan pimpinan serta kurangnya kepedulian atau dukungan dari pimpinan baik dukungan moral dan dukungan moril dalam memberikan tugastugas kantor. Hal tersebut akan mempengaruhi prestasi kerja, namun dapat memelihara dan meningkatkan disiplin yang baik bukan hal yang mudah, karena banyak faktor yang mempengaruhinya. Peraturan Pemerintah (PP) Nomor 53 Tahun 2010 tentang Disiplin Pegawai Negeri Sipil merupakan pedoman perilaku bagi PNS.

2. Dalam hal pemberian hukuman disiplin jam kerja bagi PNS pada BKPSDM yang tidak disiplin sudah dilaksanakan berupa teguran lisan maupun teguran tertulis tetapi masih saja ada pegawai yang mengulangi pelanggaran tersebut. Pemberian hukuman disiplin kepada PNS yang tidak disiplin dalam hal tidak tepat waktu dalam pekerjaan yang diberikan atau tidak mencapai Sasaran Kerjanya, diberikan teguran secara lisan dan pemotongan TPP sebesar 3\% sesuai dengan pengurangan yang ada dalam aplikasi TPP.

3. Faktor-faktor yang menghambat pada Implementasi Hukuman Disiplin Jam Kerja PNS pada BKPSDM, yaitu: komunikasi yang kurang efektif, sumber daya pegawai dan peralatan yang terbatas, belum tersedianya SOP tentang penjatuhan hukuman disiplin di setiap bidang, dan kurang tegasnya atasan dalam pengambilan keputusan serta belum dilakukannya pemberian reward dan punishment terhadap PNS yang tepat waktu dalam menyelesaikan pekerjaan kantor.

\section{DAFTAR PUSTAKA}


[1] Nomor 53 Tahun 2010 tentang Disiplin Pegawai Negeri Sipil

[2] Lumingkewas, Lexie. A. 2018. Pengantar Analisis Kebijakan Publik, Teori dan Aplikasi. Malang: Wineka Media

[4] Nugroho, Riant. 2008. Public Policy, Jakarta: PT. Elex Media Komputindo

[5] Wahab, Solichin. 2004. Analisis Kebijaksanaan: Dari Formulasi Ke. Implementasi Kebijaksanaan Negara. Jakarta: Bumi Aksara.

[6] Soeprapto, Krisdarto. 2001. Menuju SDM Berdaya. Jakarta: Alex Media. Kompatindo.

[7] Sugiyono. 2014. Metode Penelitian Kuantitatif, Kualitatif dan Kombinasi (Mixed Methods). Bandung: Alfabeta

[8] Moleong, Lexy J.2013. Metode Penelitian Kualitatif. Edisi Revisi. Bandung: PT.Remaja Rosdakarya

[9] Creswell, J.W. 2007. Qualitative inquiry \& research design choosing among five approaches. Second edition. Sage PublicationsCalifornia

[10] Robbins SP, dan Judge. 2007. Perilaku Organisasi, Salemba Empat, Jakarta.

[11] Dunn, William. N. 2000. Pengantar Analisa Kebijakan Publik. Yogyakarta: Gadjah Mada Press 